\title{
T-138C polymorphism of $M G P$ gene is associated with blood plasma cholesterol levels but not related to other risk factors of atherosclerosis in patients with ischemic stroke
}

\author{
V. Yu. Garbuzova', A. V. Polonikov' ${ }^{2}$ Y. A. Ataman', T. I. Mychaylova', \\ O. A. Obukhova ${ }^{1}$, O. I. Matlaj ${ }^{1}$, A. V. Ataman ${ }^{1}$ \\ ${ }^{1}$ Sumy State University \\ 2, Rimskogo-Korsakova Str., Sumy, Ukraine, 40007 \\ ${ }^{2}$ Kursk State Medical University \\ 3, Karl Marx Str., Kursk, Russian Federation, 305041 \\ ataman_av@mail.ru
}

\begin{abstract}
Aim. To analyse the association of MGP gene promotor T-138C polymorphism (rs 1800802) with known risk factors of atherosclerosis and its complications (hypercholesterolemia, hypertension, high body mass index, diabetes, smoking, hypercoagulability) in patients with ischemic stroke (IS) of atherothrombotic origin. Methods. Venous blood of 170 IS patients was used for genotyping. The MGP gene polymorphism was examined by PCRRFLP methodology. Results. The carriers of a minor allele $(T / C+C / C)$ had higher total cholesterol $(5.4 \pm 0.19$ vs $4.8 \pm 0.15 \mathrm{mmol} / \mathrm{l}, P=0.025)$ and $L D L$-cholesterol concentrations $(3.6 \pm 0.17$ vs $3.0 \pm 0.14 \mathrm{mmol} / \mathrm{l}, P=$ $=0.008)$, and lower HDL-cholesterol level (0.96 $\pm 0,04$ vs $1.1 \pm 0.03 \mathrm{mmol} / \mathrm{l}, P=0.029)$ in blood plasma than the major allele homozygotes (T/T). Conclusions. It has been found no association between T-138C polymorphism of MGP gene and known risk factors for atherosclerosis and its complications (BMI, hypertension, diabetes, smoking, hypercoagulability) in patients with IS from the northeastern region of Ukraine. IS patients with the minor allele have more pronounced atherogenic changes in blood plasma lipoproteins as compared with the major allele homozygotes.
\end{abstract}

Keywords: arterial calcification, ischemic stroke, matrix Gla protein, single nucleotide polymorphism.

Introduction. Matrix gamma-carboxyglutamic acid protein (MGP) is a mineral-binding extracellular protein synthesized in the vascular tissue. It belongs to a family of proteins that contain glutamyl residues, posttranslationally modified by vitamin K-dependent gamma-glutamyl carboxylase into gamma-carboxyglutamic acid (Gla) residues [1].

MGP is known to be one of the most potent natural inhibitors of ectopic mineralization. The homozygous MGP deficient mice were observed to die within 8 weeks as a result of arterial calcification that led to blood vessel rupture [2]. MGP is highly expressed on calcified

(C) Institute of Molecular Biology and Genetics, NAS of Ukraine, 2014 atherosclerotic plaques in humans [3], and it can modify calcification in such plaques and the risk of cardiovascular disease [4-6]. It is thought that anticalcifying activity of MGP depends on Gla-residues, which are able to bind calcium [7].

The human MGP gene located on the chromosome 12 p13.1-p12.3 consists of 4 exons [8]. Numerous single nucleotide polymorphisms (SNPs) were identified in both the coding and regulatory regions of $M G P$ gene. Among those, the T-138C polymorphism of gene promoter was under consideration in a number of studies [9-15]. In vitro investigations suggest that $\mathrm{T}-138 \mathrm{C}$ polymorphism in $M G P$ is associated with altered promotor activity $[11,13,14]$. In addition, there is some 
evidence that this variant of SNP is related to the level of serum MGP, arterial calcification, and coronary artery disease $[9-11,13]$, although these data are not consistent $[14,15]$.

Ischemic stroke (IS) is, in many instances, the consequence of a thrombus forming on a ruptured atherosclerotic plaque. Abnormal calcium salts content in the arterial vessels is considered to be a novel marker of atherosclerosis and related to cerebrovascular disease [16].

Considering the central role of MGP in vascular calcification and similar pathogenesis of the coronary artery disease and severe cerebrovascular events, we hypothesized that the T-138C polymorphism in MGP gene promoter might influence the risk of IS.

In our previous studies no association has been found between the T-138C polymorphism of $M G P$ gene and IS in the representatives of the northern region of Ukraine [17].

The purpose of the present study was to analyse the association of the $M G P$ gene promotor polymorphism with well the established risk factors of atherosclerosis and its complications such as hypercholesterolemia, hypertension, high body mass index, diabetes, smoking, and hypercoagulability in the patients with IS of atherothrombotic origin.

Materials and methods. Study subjects. Studied a group included 170 unrelated Ukrainian patients with a mean age of $64.8 \pm 9.5$ years who had IS and had been under medical surveillance and outpatient treatment in the $5^{\text {th }}$ Sumy Clinical Hospital since 2009 to 2011. A final diagnosis of IS was established on the basis of clinical, computed tomography and magnetic resonance imaging investigations. Each case of IS was assessed according to the TOAST criteria [18]. The patients with IS of cardioembolic origin and undetermined etiology were excluded from the studied group. The clinical signs included generally accepted parameters related to the risk factors for atherosclerosis and atherothrombotic IS: body mass index (BMI), blood pressure (BP), the content of lipids and lipoproteins in blood plasma, and some indices of blood coagulation (prothrombin time). According to these parameters all patients were divided into the pairs of subgroups defined by (1) BMI ( $<27$ or $\geq 27 \mathrm{~kg} / \mathrm{m}^{2}$ ), (2) BP (non-hypertensive or hypertensive: systolic BP > $140 \mathrm{mmHg}$, diastolic $\mathrm{BP}>90 \mathrm{mmHg}$ ),
(3) low density lipoprotein cholesterol (LDL-C) concentration ( $\leq 3.5$ or $>3.5 \mathrm{mmol} / \mathrm{l})$, (4) diabetes mellitus type 2 (non-diabetic or diabetic), (5) smoking (nonsmoking or smoking), and (6) prothrombin time ( $\geq 9$ or $<9$ ").

The study had been previously approved by the Ethic Committee on Medical Research of the Medical Institute of Sumy State University. An appropriate informed consent was obtained from all patients. Blood sampling for genotyping was performed under sterile conditions into $2.7 \mathrm{ml} \mathrm{S}$-Monovette («Sarstedt», Germany) containing EDTA potassium salt as an anticoagulant, the samples were frozen and stored at $-20{ }^{\circ} \mathrm{C}$.

Amplification and genotyping. DNA for genotyping was extracted from venous blood using commercially available kits («Isogene Lab Ltd», Russian Federation) according to the manufacturer's protocol. To identify the $M G P$ promotor T-138C polymorphism (rs 1800802) PCR with subsequent restriction fragment length polymorphism (RFLP) analysis was performed. Specific region of the $M G P$ gene was amplified using a pair of specific primers: upstream (sense) - 5'-AAGC ATACGAAGGCCAAAACTTCTGCA-3' and downstream (antisense) - 5'-GAACTAGCATTGGAACTT TTCCCAACC-3'. Primers were provided by Metabion (Germany). PCR was performed for 33 cycles in a $25 \mu 1$ volume containing 50-100 ng of DNA, $5 \mu \mathrm{l} 5 \times$ PCRbuffer, $1.5 \mathrm{mM}$ magnesium sulfate, $200 \mu \mathrm{M}$ of each dNTP, 20 pM of each primer and $0.5 \mathrm{U}$ of Taq DNA polymerase («Fermentas», Lithuania). PCR was carried out in a termocycler GeneAmp PCR System 2700 («Applied Biosystems», USA). Six microlitres $(6 \mu \mathrm{l})$ of the PCR products (142 bp) were subjected to digestion with $3 \mathrm{U}$ BseNI («Fermentas») and incubated at $37{ }^{\circ} \mathrm{C}$ for $18 \mathrm{~h}$. The presence of thymine at position -138 of the promoter prevented the restriction and in the case of substitution for cytosine BseNI cleaved the amplified fragment of the promoter into two fragments $118 \mathrm{bp}$ and $24 \mathrm{bp}$ in length. The restriction fragments were separated by electrophoresis and analysed on the ethidium bromide-stained $2.5 \%$ agarose gel using ultraviolet transillumination.

Statistical analysis. The normal distribution and homogeneity of variances were tested before further statistical analyses. The $\chi^{2}$-test was used to assess the deviations from the Hardy-Weinberg equilibrium for ge- 
Table 1

Clinical characteristics of ischemic stroke patients with different MGP gene T-138C genotype

\begin{tabular}{|c|c|c|c|c|}
\hline Parameter & $\mathrm{T} / \mathrm{T}$ & $\mathrm{T} / \mathrm{C}+\mathrm{C} / \mathrm{C}$ & Total & $\mathrm{P}$ \\
\hline Gender, M/F & $58 / 46$ & $40 / 26$ & $98 / 72$ & 0.534 \\
\hline BMI (M), kg/m² & $27.8 \pm 0.6$ & $27.4 \pm 0.6$ & $27.6 \pm 0.4$ & 0.703 \\
\hline Systolic BP, mmHg & $168.0 \pm 2.9$ & $165.4 \pm 3.5$ & $167.0 \pm 2.2$ & 0.573 \\
\hline Diastolic BP, mmHg & $96.3 \pm 1.7$ & $93.9 \pm 1.6$ & $95.4 \pm 1.2$ & 0.348 \\
\hline Total cholesterol*, mmol/l & $4.8 \pm 0.15$ & $5.4 \pm 0.19$ & $5.0 \pm 0.12$ & 0.025 \\
\hline Triglyceride*, mmol/1 & $1.7 \pm 0.08$ & $1.8 \pm 0.1$ & $1.7 \pm 0.06$ & 0.523 \\
\hline Prothrombin time, $\mathrm{s}$ & $9.6 \pm 0.2$ & $9.3 \pm 0.24$ & $9.5 \pm 0.2$ & 0.320 \\
\hline Fasting glucose, mmol/l & $5.9 \pm 0.15$ & $6.0 \pm 0.19$ & $5.9 \pm 0.12$ & 0.792 \\
\hline Diabetes, $(\%)$ & $18(17.3)$ & $12(18.2)$ & $30(17.6)$ & 0.884 \\
\hline Smoking, $(\%)$ & $32(30.8)$ & $18(27.3)$ & $50(29.4)$ & 0.626 \\
\hline
\end{tabular}

$\mathrm{N}$ o t e. Data are mean $\pm \mathrm{SE} ; n$ - number of subjects; HDL - high density lipoprotein; LDL - low density lipoprotein; * $n=96$ for T/T genotype and $n=61$ for $\mathrm{T} / \mathrm{C}+\mathrm{C} / \mathrm{C}$ genotypes.

notype frequencies, and it was also used for comparison of the allele and genotype frequencies between different studied subgroups. Since there were few individuals with the CC genotype, we tested whether the variable means differed significantly between the subjects with and without the $\mathrm{C}$ variant (TC $+\mathrm{CC} v s \mathrm{TT}$ ). The comparison of variables between the groups of genotypes was performed using ANOVA or two-tailed Student's $t$-test. The differences were considered statistically significant with a P-value $<0.05$. All statistical analyses were performed using the Statistical Package for Social Science program (SPSS for Windows, version 17.0, SPSS Inc., Chicago, IL).

Results and discussion. The known IS risk factors include increased BMI, hypertension, elevated levels of cholesterol and LDL in blood plasma, diabetes mellitus, hypercoagulability, and smoking, i. e. factors relating to atherogenesis and thrombi formation. In Table 1 some clinical characteristics manifesting the abovementioned IS risk factors inherent to the patients divi- ded into two subgroups according to their genotype $(\mathrm{T} / \mathrm{T}$ and $\mathrm{T} / \mathrm{C}+\mathrm{C} / \mathrm{C})$. The statistically significant differences are revealed between these two subgroups only for cholesterol levels. The carriers of minor allele (T/C + $+\mathrm{C} / \mathrm{C})$ had higher total cholesterol $(5.4 \pm 0.19$ vs $4.8 \pm$ $\pm 0.15 \mathrm{mmol} / \mathrm{l}, \mathrm{P}=0.025)$ and LDL-cholesterol concentrations $(3.6 \pm 0.17$ vs $3.0 \pm 0.14 \mathrm{mmol} / 1, \mathrm{P}=0.008)$, and lower HDL-cholesterol level $(0.96 \pm 0,04$ vs $1.1 \pm$ $\pm 0.03 \mathrm{mmol} / \mathrm{l}, \mathrm{P}=0.029)$ than the major allele homozygotes (T/T).

The division of patients into subgroups according to the presence or absence of known stroke risk factors allowed a comparative analysis of the partition of their genotypes. As shown in Table 2, statistically significant differences were not established for any comparison.

Arterial wall calcification is a common pathological process that is of significance by itself (Monckeberg's sclerosis) and can complicate the development of atherosclerotic plaques contributing to their instability. Therefore, investigation of the factors related to the 
Table 2

Distribution of genotypes by the T-138C polymorphism of the MGP gene in subgroups of IS patients with regards to different disease risk factors $(\%)$

\begin{tabular}{|c|c|c|c|c|}
\hline $\mathrm{T} / \mathrm{T}$ & 48 (60.7) & $56(61.5)$ & $25(59.5)$ & 79 (61.7) \\
\hline $\mathrm{T} / \mathrm{C}$ & $24(30.4)$ & 29 (31.9) & $13(31.0)$ & $40(31.3)$ \\
\hline $\mathrm{C} / \mathrm{C}$ & $7(8.9)$ & $6(6.6)$ & $4(9.5)$ & $9(7.0)$ \\
\hline $\mathrm{P}$ & 0.852 & 0.852 & & \\
\hline \multirow{2}{*}{ Genotype } & \multicolumn{2}{|c|}{ Diabetes, $n(\%)$} & \multicolumn{2}{|c|}{ Smoking, $n(\%)$} \\
\hline & Non-diabetic & Diabetic & Non-smoking & Smoking \\
\hline In total, $n$ & 140 & 30 & 120 & 50 \\
\hline $\mathrm{P}$ & \multicolumn{2}{|c|}{0.866} & \multicolumn{2}{|c|}{0.829} \\
\hline
\end{tabular}

$\mathrm{N}$ o t e. $n$ - number of subjects; BMI - body mass index; LDL-C - low density lipoprotein cholesterol; PT - prothrombin time; $* 13$ patients without data on this index were excluded from calculation.

mechanisms of vascular calcification is of increased interest, as evidenced by a number of literature sources $[5,19-21]$.

$M G P$ is well known to play a pivotal role in preventing the blood vessels mineralization. An exact mechanisms by which $M G P$ inhibits the ectopic soft tissues calcification are not yet clear. The data on relationship between $M G P$ and the calcifying vascular lesions are contradictory. Thus, Braam et al. [22] showed that the development of severe atherosclerosis was accompanied by an increase in the serum MGP concentration. In contrast, Jono et al. [23] found that the serum $M G P$ levels inversely correlated with the coronary artery calcification. Finally, O'Donell et al. [24], showing the relationship between the level of $M G P$ and a number of risk factors, found no correlation between the serum MGP concentration and calcification of the coronary arteries.

With regard to the association between $M G P$ gene polymorphisms and (a) the serum levels of the protein, (b) arterial calcification, and (c) the severe consequences of atherosclerosis, this problem has not been investigated (as for the brain vessels and ischemic stroke) or has been limited to the studies on the coronary arteries and coronary artery disease complications (acute coronary syndrome, myocardial infarction). It should be mentioned that the results of these few studies are not consistent.

Thus, Farzaneh et al. [11] found the statistically significant association between the $M G P$ promoter T$138 \mathrm{C}$ polymorphism and serum $M G P$ concentration in the healthy individuals from Netherlands. In contrast to this, Crosier et al. [10] could not find any relation between T-138C polymorphism and the levels of $M G P$ in the blood serum of healthy older males and females of European descent from Massachusetts (USA). In the same study, the association of two other MGP polymorphisms (G-7A and Thr83Ala) with the serum $M G P$ concentration was shown. Various methods of analysis revealed that in males, homozygous carriers of the minor allele, the T-138C polymorphism of the $M G P$ gene was associated with a decreased level of coronary artery calcification, relative to the major allele carriers [10]. Such association was not found in females.

In the Coronary Artery Risk Development in Young Adults (CARDIA) study, the population-based investigation of cardiovascular disease in young African-Ame- 
rican and non-Hispanic white participants, the T-138C polymorphism of the MGP gene was analysed regarding the association with the presence or absence of coronary artery calcification [13]. This SNP was also studied in autopsy samples for an association with several measures of atherosclerotic calcification [14]. However, no connection between the T-138C polymorphism and vascular calcification was found in either of these studies.

Italian scientists defined the distribution of $M G P$ promoter T-138C polymorphism in patients with chronic kidney disease (CKD) and age- and sex marched healthy controls [9]. It was shown that the frequency of the major $\mathrm{T}$ allele was significantly higher in the CKD group versus controls. T/T homozygotes were associated with cardiovascular events in CKD patients. It was concluded that some $M G P$ gene polymorphisms might be a negative prognostic factor for the progression of CKD and for severe cardiovascular disorders.

It should be noted that the majority of studies cited here were devoted to the relation of $M G P$ to coronary artery calcification and myocardial infarction. As to cerebral artery atherosclerosis and its severe events such as IS, the role of arterial calcification in this disease and the association of $M G P$ with cerebrovascular pathologies were the subject of investigation and discussion only in a few publications. In particular, Bos et al. [16] established a close relationship between calcification in the various vessel beds outside the brain and imaging markers of vascular brain disease. Calcification in each vessel bed was shown to be associated with the presence of cerebral infarcts and with a larger volume of white matter lesions (WMLs). The most prominent associations were found between the intracranial carotid calcification and WML volume and between the extracranial carotid calcification and infarcts.

Acar et al. [25] studied a relation of serum MGP levels to the development of intracerebral hemorrhages (ICH) and found that in patients with $\mathrm{ICH}$, the serum $M G P$ concentration was much lower than in control group. Moreover, in the non-survivors, the serum $M G P$ levels were significantly lower in comparison to the survivors. According to the authors, measurement of this parameter may be of value to estimate mortality.

At present, there are only a few publications concerning relation of the MGP SNPs to cerebrovascular disease. Del Rio-Espinola et al. [26] tried to find genetic predictors of reocclusion after successful fibrinolytic therapy during the acute phase of IS. Analysing 236 polymorphisms, they revealed an association between the $M G P$ G-7A polymorphism and reocclusion risk. According to the authors, the predictive scale that was generated permits the stratification of patients by their reocclusion risk with a higher accuracy than clinical parameters only.

In our previous study, we have defined the distribution of genotypes for the $M G P$ promoter T-138C polymorphism in IS and control patients from the northeastern region of Ukraine [17]. We have not found any association between this SNP and stroke. The distribution of $\mathrm{T} / \mathrm{T}, \mathrm{T} / \mathrm{C}$ and $\mathrm{C} / \mathrm{C}$ genotypes in patients with IS was $61.2,31.2$ and $7.6 \%$ respectively. The corresponding distributions in the control group were 59.7, 35.6, $4.8 \%\left(\mathrm{P}=0.521\right.$ by the $\chi^{2}$ test $)$. Almost the same results were obtained when all patients were divided by gender.

As shown in this paper, no correlation has also been found between the T-138C genotypes and IS risk in the subgroups of IS patients formed according to the presence or absence of known risk factors of atherosclerosis (BMI, hypertension, hypercholesterolemia, diabetes, smoking, hypercoagulability). Only with regards to the plasma lipoproteins cholesterol concentrations, the statistically significant differences were revealed between the carriers of different allelic variants of the $M G P$ gene. In IS patients who are the carriers of a minor allele $-138 \mathrm{C}$ (genotypes $\mathrm{T} / \mathrm{C}$ and $\mathrm{C} / \mathrm{C}$ ), the levels of total cholesterol and LDL-cholesterol were higher and the concentration of HDL-cholesterol was lower than in the persons with $\mathrm{T} / \mathrm{T}$ genotype. It could mean that the presence of the $-138 \mathrm{C}$ allele predisposes to more pronounced atherogenic changes in the blood plasma lipoproteins. Atherosclerotic plaques and thrombi are able to cause atherothrombotic ischemic stroke, one of the most common pathogenetic variants of stroke.

The influence of T-138C polymorphism on various pathological processes can be realized through the changes in the $M G P$ promoter activity. In [13], an analysis of the $M G P$ promoter activity revealed that the $-138 \mathrm{C}$ allele reduced the promoter activity by $20 \%$ in the rat vascular smooth muscle cells (VSMC) and by up to $50 \%$ in the human fibroblast cell line. Moreover, it was demonstrated that a nuclear protein was specifically bound in the region covering the $\mathrm{T}-138 \mathrm{C}$ polymorphic 
site, and that the binding was enhanced in the presence of the $\mathrm{T}$ allele. Thus, the difference in the promoter activity might be explained by differential binding of a nuclear protein that is important in MGP transcription.

In another study [11], the influence of T-138C polymorphism on gene expression was examined using the reporter gene constructs transiently transfected into VSMCs. It was demonstrated that this SNP impacted the transcriptional activity of the $M P G$ gene. The activity of $-138 \mathrm{C}$ variant of promoter was 4 times higher than that of the $-138 \mathrm{~T}$ variant. On the other hand, it was shown that the $-138 \mathrm{~T}$ allelic variant bound AP-1 complexes and was induced by the phorbol 12-myristate 13 -acetate treatment, while the $-138 \mathrm{C}$ variant was resistant to the compound, confirming that AP-1 factors preferentially are bound to the $-138 \mathrm{~T}$ variant. It was suggested that the $-138 \mathrm{C}$ variant provided protection against tissue calcification in VSMC due to higher levels of the MGP transcription. Equally, the responsiveness of the $-138 \mathrm{~T}$ site to extracellular stimuli mediated via AP-1 may result in altered susceptibility to calcification. Clearly, these results are inconsistent with the above-mentioned findings [13].

Conclusions. No association has been found between the T-138C polymorphism of $M P G$ gene and known risk factors for atherosclerosis and its complications (BMI, hypertension, diabetes, smoking, hypercoagulability) in the patients with IS from the northeastern region of Ukraine. However, in the carriers of the minor allele (genotypes $\mathrm{T} / \mathrm{C}$ and $\mathrm{C} / \mathrm{C}$ ) the levels of total cholesterol and LDL-cholesterol were higher and the concentration of HDL-cholesterol was lower than in the persons with the T/T genotype. It means that the IS patients with the minor allele have more pronounced atherogenic changes in the blood plasma lipoproteins as compared with the major allele homozygotes.

Поліморфізм T-138С гена MGP асоційований з рівнями холестеролу плазми крові і не пов'язаний з іншими факторами ризику атеросклерозу у пацієнтів з ішемічним інсультом

В. Ю. Гарбузова, О. В. Полоніков, Ю. О. Атаман, Т. І. Михайлова, О. А. Обухова, О. І. Матлай, О. В. Атаман

Резюме

Мета. Проаналізувати зв'язок поліморфізму T-138С промотору гена MGP (rs1800802) з відомими факторами ризику атеросклерозу та його ускладнень (гіперхолестеролемія, гіпертензія, висо- кий показник індексу маси тіла, иукровий діабет, куріння, підвищена коагуляційна здатність крові) у пацієнтів з ішемічним інсультом атеротромботичного походження. Методи. Для генотипування використано венозну кров 170 хворих на ішемічний інсульт. Поліморфізм гена MGP визначено методом полімеразної ланцюгової реакиії з наступним аналізом довжини рестрикиійних фрагментів при виявленні їх електрофорезом в агарозному гелі. Результати. Носії мінорного алеля $(T / C+C / C)$ мали вищі показники загального холестеролу (5,4 $\pm 0,19$ проти 4,8 $\pm 0,15$ ммоль/л, $P=0,025)$ і холестеролу ліпопротеїнів низької густини $(3,6 \pm 0,17$ проти 3,0 \pm 0,14 ммоль/л, $P=0,008)$, а також нижчий рівень холестеролу ліпопротеїнів високої густини у плазмі крові, ніж гомозиготи за основним алелем (T/T). Висновки. Не знайдено зв 'язку між поліморфізмом T-138С гена MGP і відомими факторами ризику атеросклерозу та його ускладнень (індексом маси тіла, гіпертензією, иукровим діабетом, курінням, підвищеною коагуляційною здатністю крові) у хворих на ішемічний інсульт з північносхідного регіону України. У пацієнтів - носіїв мінорного алеля - зареєстровано вираженіші зміни ліпопротеїнів плазми крові атерогенного характеру порівняно з гомозиготами за основним алелем.

Ключові слова: кальцифікація артерій, ішемічний інсульт, матриксний білок Gla, поліморфізм поодиноких нуклеотидів.

Полиморфизм T-138C гена MGP ассоциирован с уровнями холестерола плазмы крови и не связан с другими факторами риска атеросклероза у пациентов с ишемическим инсультом

В. Ю. Гарбузова, А. В. Полоников, Ю. А. Атаман,

Т. И. Михайлова, О. А. Обухова, О. И. Матлай, А. В. Атаман

Резюме

Цель. Проанализировать связь полиморфизма Т-138С промотора гена MGP (rs1800802) с известными факторами риска атеросклероза и его осложнений (гиперхолестеролемия, гипертензия, высокий показатель индекса массы тела, сахарный диабет, курение, повышенная коагуляионная способность крови) у паџиентов с ишемическим инсультом атеротромботического происхождения. Методы. Для генотипирования использовали венозную кровь 170 больных ишемическим инсультом. Полиморфизм гена MGP определяли методом полимеразной цепной реакции с последующим анализом длины рестрикиионных фрагментов при их выявлении электрофорезом в агарозном геле. Результаты. Для носителей минорного аллеля $(T / C+C / C)$ характерны более высокие показатели общего холестерола $(5,4 \pm 0,19$ против 4,8 \pm $\pm 0,15$ ммоль/л, $P=0,025)$ и холестерола липопротеинов низкой плотности (3,6 \pm 0,17 против 3,0 \pm 0,14 ммоль/л, $P=0,008), a$ также более низкий уровень холестерола липопротеинов высокой плотности в плазме крови, чем у гомозигот по основному аллелю (T/T). Выводы. Не установлено связи между полиморфизмом T-138C гена MGP и известными факторами риска атеросклероза и его осложнений (индексом массы тела, гипертензией, сахарным диабетом, курением, повышенной коагуляционной способностью крови) у больных с ишемическим инсультом из северовосточного региона Украины. У пациентов - носителей минорного аллеля - зарегистрированы более выраженные изменения липопротеинов плазмы крови атерогенного характера по сравнению с гомозиготами по основному аллелю.

Ключевые слова: кальцификаџия артерий, ишемический инсульт, матриксный Gla-протеин, полиморфизм одиночных нуклеотидов. 


\section{REFERENCES}

1. Shanahan CM, Proudfoot D, Tyson KL, Cary NRB, Edmonds $M$, Weissberg $P L$. Expression of mineralisation-regulating proteins in association with human vascular calcification. Z Kardiol. 2000; 89(Suppl. 2):63-8.

2. Luo G, Ducy P, McKee MD, Pinero GJ, Loyer E, Behringer RR, Karsenty $G$. Spontaneous calcification of arteries and cartilage in mice lacking matrix Gla protein. Nature. 1997; 386(6620):78-81.

3. Proudfoot D, Skepper JN, Shanahan CM, Weissberg PL. Calcification of human vascular cells in vitro is correlated with high levels of matrix Gla protein and low levels of osteopontin expression. Arterioscler Thromb Vasc Biol. 1998; 18(3):379-88.

4. Dhore CR, Cleutjens JP, Lutgens E, Cleutjens KB, Geusens PP, Kitslaar PJ, Tordoir JH, Spronk HM, Vermeer C, Daemen MJ. Differential expression of bone matrix regulatory proteins in human atherosclerotic plaques. Arterioscler Thromb Vasc Biol. 2003; 21(12):1998-2003.

5. Doherty TM, Fitzpatrick LA, Inoue D, Qiao JH, Fishbein MC, Detrano RC, Shah PK, Rajavashisth TB. Molecular, endocrine, and genetic mechanisms of arterial calcification. Endocr Rev. 2004; 25(4):629-72.

6. Shearer MJ. Role of vitamin $\mathrm{K}$ and Gla proteins in the pathophysiology of osteoporosis and vascular calcification. Curr Opin Clin Nutr Metab Care. 2000; 3(6):433-38.

7. Murshed M, Schinke T, McKee MD, Karsenty G. Extracellular matrix mineralization is regulated locally: different roles of two gla-containing proteins. J Cell Biol. 2004; 165(5):625-30.

8. Cancela L, Hsieh CL, Francke U, Price PA. Molecular structure, chromosome assignment, and promoter organization of the human matrix Gla protein gene. J Biol Chem. 1990; 265(25):15040-8.

9. Brancaccio D, Biondi $M L$, Gallieni M, Turri O, Galassi A, Cecchini F, Russo D, Andreucci $V$, Cozzolino M. Matrix GLA protein gene polymorphisms: clinical correlates and cardiovascular mortality in chronic kidney disease patients. Am J Nephrol. 2005; 25 (6):548-52.

10. Crosier MD, Booth SL, Peter I, Dawson-Hughes B, Price PA, $O$ 'Donnell CJ, Hoffmann U, Wiilliamson MK, Ordovas JM. Matrix Gla protein polymorphisms are associated with coronary artery calcification in men. J Nutr Sci Vitaminol (Tokyo). 2009; 55 (1):59-65.

11. Farzaneh-Far A, Davies JD, Braam LA, Spronk HM, Proudfoot $D$, Chan SW, O'Shaughnessy KM, Weissberg PL, Vermeer $C$, Shanaham CM. A polymorphism of the human matrix gammacarboxyglutamic acid protein promoter alters binding of an activating protein- 1 complex and is associated with altered transcription and serum levels. J Biol Chem. 2001; 276(35):32466-73.

12. Hernandez-Pacheco G, Murguia LE, Rodriguez-Perez JM, Fragoso JM, Perez-Vielma N, Martinez-Rodriguez N, Granados J, Vargas-Alarcon $G$. Matrix gamma-carboxyglutamic acid protein (MGP) G-7A and T-138C gene polymorphisms in Indian (Mayo and Teenek) and Mestizo populations from Mexico. Hum Biol. 2005; 77(3):385-91.

13. Herrmann SM, Whatling C, Brand E, Nikaud V, Gariepy J, Simon A, Evans A, Ruidavets LB, Arveiler D, Luc G, Tiret L, Henney A, Cambien $F$. Polymorphisms of the human matrix gla protein
(MGP) gene, vascular calcification, and myocardial infarction. Arterioscler Thromb Vasc Biol. 2000; 20(11):2386-93.

14. Kobayashi N, Kitazawa R, Maeda S, Schurgers LJ, Kitazawa S. $\mathrm{T}-138 \mathrm{C}$ polymorphism of matrix gla protein promoter alters its expression but is not directly associated with atherosclerotic vascular calcification. Kobe J Med Sci. 2004; 50(3-4):69-81.

15. Taylor BC, Schreiner PJ, Doherty TM, Fornage M, Carr JJ, Sidney $S$. Matrix Gla protein and osteopontin genetic associations with coronary artery calcification and bone density: the CARDIA study. Hum Genet. 2005; 116(6):525-8.

16. Bos D, Ikram MA, Elias-Smale SE, Krestin GP, Hofman A, Witteman JC, van der Lugt A, Vernooij $M W$. Calcification in major vessel beds relates to vascular brain disease. Arterioscler Thromb Vasc Biol. 2011; 31(10):2331-7.

17. Ataman AV, Garbusova VY, Ataman YA, Matlaj OI, Obuchova OA. Investigation of the MGP promoter and exon 4 polymorphisms in patients with ischemic stroke in the Ukrainian population. $J$ Cell Mol Biol. 2012; 10(1):19-26.

18. Adams HP, Bendixen BH, Kappelle LJ, Biller J, Love BB, Gordon DL, Marsh EE. Classification of subtype of acute ischemic stroke. Definitions for use in a multicenter clinical trial. TOAST. Trial of Org 10172 in Acute Stroke. Treatment Stroke. 1993; 24(1):35-41.

19. Abedin M, Tintut $Y$, Demer LL. Vascular calcification. Mechanisms and clinical ramifications. Arterioscler Thromb Vasc Biol. 2004; 24(7):1161-70.

20. Atkinson J. Age-related medial elastocalcinosis in arteries: mechanisms, animal models, and physiological consequences. $J$ Appl Physiol. 2008; 105(5):1643-51.

21. Guzman RJ. Clinical, cellular, and molecular aspects of arterial calcification. J Vasc Surg. 2007; 45(Suppl. A):A57-A63.

22. Braam LA, Dissel P, Gijsbers BL, Spronk HMH, Hamulyak K, Soute B. AM, Debie $W$, Vermeer $C$. Assay for human matrix gla protein in serum: potential applications in the cardiovascular field. Arterioscler Thromb Vasc Biol. 2000; 20(5):1257-61.

23. Jono $S$, Vermeer $C$, Dissel P, Hasegava K, Shioi A, Taniwaki H, Kizu A, Nishizawa Y, Saito $S$. Matrix Gla protein is associated with coronary artery calcification as assessed by electron-beam computed tomography. Thromb Haemost. 2004; 91(4):790-4.

24. O'Donnell CJ, Kyla Shea M, Price PA, Gagnon DR, Wilson $P W F$, Larson MG, Kiel DP, Hoffmann U, Ferencik M, Clouse ME, Williamson MK, Cupples LA, Dawson-Hughes B, Booth SL. Matrix Gla protein is associated with risk factors for atherosclerosis but not with coronary artery calcification. Arterioscler Thromb Vasc Biol. 2006; 26(12):2769-74.

25. Acar A, CevikMU, Arikanoglu A, Evliyaoglu O, Basarili MK, Uzar E, Ekici F, Yucel Y, Tasdemir N. Serum levels of calcification inhibitors in patients with intracerebral hemorrhage. Int J Neurosci. 2012; 122(5):227-32.

26. del Rio-Espinola A, Fernandez-Cadenas I, Rubiera M, Quintana $M$, Domingues-Montanari $S$, Mendioroz M, FernandezMorales J, Giralt D, Molina CA, Alvarez-Sabin J, Montaner J. CD40-1 C > T polymorphism (rs1883832) is associated with brain vessel reocclusion after fibrinolysis in ischemic stroke. Pharmacogenomics. 2010; 11(6):763-72.

Received 30.03.13 